\title{
Facilitating Government Business On-line: The Electronic Transactions Act 1999
}

\section{George Cho and Eagene Clark}

1 overnment business on-liine as well as the generic electronic business (ebusiness) and electronic commerce ( $t$-commerce) are major concerns for governments, businesses and citizen; alike. In particular the common objective of all parties is to make such electonic transactions efficient, effective and acceptable. But there are barriers in ahieving these objectives. While ecommerce is becoming an essenttial part of business developments nationally and internationally, consumer conficlence is laciing. This is because of fears of insecure payments and receiptt systems, legal protection and jurisdictional problems when trading in borderless cyber-space, the fear of the loss of personal privacy, the resolution of on-line disputes ard the issue of taxation of electronic transactions.

This article presents as assessment of the Australian government's response in addressing these issues especially in regard to doing government business online. To build more confidence in e-business the government's aim is to lead by example so that all Commonwealth agencies become fully engaged in electronic transactions by 2001. To encourage this devilopment the government has passed relevant legislation that will create an envionment in which confidence in ecommerce can prosper. However, there are jroblems confronting this policy and an evaluation is required of whether it may achieve a high degree of confidence in e-commerce. A background to the Internet and e-commerce in Australia is given in the first section before discussing the gorernment's major legislation - the Electronic Transaction Act (ETA) - in the noxt section. The ETA's raison d'être is then assessed in the third section in the ligit of its workability, practicality and technicality before a concluding section which gives an overall evaluation of the ETA.

\section{The Internet and E-commerce in Austrilia}

Australia's transformation from an industrial to an information society inevitably means that more and more trade and commere will take place in an electronic or cyber-world. Such a world inceludes the ise of the digital phone, Intranets, electronic data interchange ((EDI), smat cards and other information communication technologies (ICT). Govemments, businesses and consumers

George Cho is Associate Profesisor of Geogaphic Information Systems and the Law and Eugene Clark is Pro Vice Chancelor, Division of Science and Design and Professor of Law. Both are members of the Information Technology Law Group at the University of Canberrra. 
cannot ignore such developments. Al obvious inidicator of such transformations is the growth of business on the Internet either in the form of servers connecting to the Internet or the number of bisiess web sittes that are being established in Australia (De Zwart, 2000).

There is a perception that $\epsilon$-commerce is san unregulated frontier in which digital marketers are free to ride the electromic range in search of markets, customers and profits. However, an opposing rview is that e-commerce can be regarded as heavily regulated in thatin all commerce whatever laws that apply to paper-based commerce also applies to the electronic variety. It is at the margins where there may be no 'paper' equivalents that e-commerce may have to depend on codes and other industry-based elf-regulatorry mechanisms. This uncertainty in law and business practice car hive a deleterrious effect on overall economic performance. For the legal praclitioner, a reliamce on private regulatory regimes may prove unsatisfactory because thre will be little available either in the form of case law for precedents or 'black later' law for guidance and interpretation. In addition, cross-border issues aboundincluding jurisdictional questions of what law applies, where to seek redress for diputes and comsumer protection.

The government's e-commercestrategy is sset out in A Strategic Framework for the Information Economy --Identifying Pricorities for Action (NOIE, 1999a). The Framework recognises that consumer prottection is an integral part of the strategy so that business to consimer e-commerce is compatible with both business to business and business 0 governmemt on-line services. A priority of this strategy is the need to develop the legal and regulatory framework to facilitate e-commerce. Such a development vill give greater confidence to all Australians in electronic transactions, provide consumers with protection when transacting electronically and have in place a regulatory framework that will generate certainty.

The Australian National AuditOffice (AN/AO) report on Electronic Services Including Internet Use by Conmonwealth Agencies evaluates Australia's readiness for the global informationeconomy. The study showed that 82 per cent of all responding agencies considered that they would meet the government's commitment that all appropriate government services will be Internet-deliverable by 2001. By that date at least haf of the government agencies would have a website that publishes information bout itself and its services, a quarter will allow Internet users to access the agency'; database, at fifth will permit access including secure information and engage in tansactions with the agencies and two per cent will be able to facilitate, with priorapproval, a sharing of information with other relevant government agencies (AN $/ 0,1999-2000: 14$ ).

Yet, significant impediments remain in regard to the goal of widespread adoption of e-commerce. These ae largely legal in nature including concerns: about the status of electronic documents, standards and procedures in implementing government regulations such as the ETA, record retention, fraud prevention, protecting personal privacy and security and misleading and deceptive conduct and practices (National Advisory Council on Consumer Affairs, 1998; Federal Bureau of Consumer Affair, 1997). 
The Electronic Commerce Expert Grap (ECEG) made up of industry, :government and other experts reported on he pressing need for legislation to :support the regulation of e-commerce transađions (ECEG 1998). This need also no doubt may have been triggered by internatonal developments around the world including the US and other Asia Pacific counries. The European Union-Australia Joint Science and Technology Cooperativ Committee has been conducting research into this area of regullation as is the OECD which is working on guidelines for tax on Internet busiiness (see ATO, 1997).

\section{The ETA: What and Why?}

The Electronic Transactions Act, 1999 (Cwth is based on the recommendations of the ECEG that reported to the Alttorney-Gereral in March 1998 (ECEG, 1998). The Expert Group recommended that the Conmonwealth enact legislation based on the UN Commission on International Tnde Law Model Law on Electronic Commerce (UNCITRAL, 1996). The ETA received Royal Assent in December 1999 and commenced by Proclamation on 15March 2000 (AGD, 1999). The Act aims to prevent the invalidation of transactions merely because they have been conducted electronically. Until 1 July 200 the ETA will only apply to those Commonwealth Acts specified in regulations. At the time of writing 278 Commonwealth Acts have been sspecified in egulations, including the Australian Prudential Regulation Act, Banking Act, Crrency Act, Financial Corporations Act, Financial Sector (Shareholdings) Act, lrivacy Act (section 63 only), Trade Practices Act (section 170 only) and various superannuation legislation. This is sixteen less than originally anticcipated. These pieces of legislation have been 'dropped' on advice of the Attorrney Genera's Department because they contain provisions that will be difficult to satisfy in an e-commerce environment. From 1 July 2001 the ETA will apply to all Commonwealth legislation (other than those specifically excluded by the regullations).

The ETA is a tool in the Government's strategy for developing the information economy in Australica. In generd the ETA allows e-commerce to fit into the same legal framework as: traditional paper-based transactions. The goal is to ensure that the technological development brought about by e-commerce can be dealt with within the existimg legal system, while allowing business and consumers to determine the most reffective tedinological choice for their purposes.

In the longer term the Commonwealth $s$ working in collaboration with the States and Territories to develop a national uriform legislative scheme to facilitate the use of electronic transactioms. The plan is for each government to enact legislation within their jurisdiction to faciltate the removal of existing legal impediments to electronic commerce. The New South Wales Electronic Transactions Act 2000 (NSW) and the Victoran. Electronic Transactions Act 2000 (Vic) mirror the ETA. The key differences between the legislation of the two states, and the ETA, are: that thie state legisations apply to the interpretation of the common law as well as legisilation; they do: not differentiate communications between private organisations and governmert bodies; and they do not provide for 
a 'staged' introduction of the Ac. The state legislations apply to all state law other than those exempted by reguations and the common law by proclamation.

The ETA has been built on thee underlying principles; namely:

- functional equivalence, or the juarantee that paper and electronic documents will be on the same legal footing;

- technology neutrality, that is, he law will not discriminate between different forms of technology; and,

- a principled approach to electronc signatures.

With the ETA the primary objective is to enable people to use electronic communications with government agencies to sattisfy their legal obligations under Commonwealth law, including the requirements tio give:

- information in writing ( 59 ;

- provide a signature (s10);

- produce a document (s11)

- record information(s 12$)$; and

- retain a document(s12).

Electronic communications can only satisfy llegal requirements if they comply with specified criteria, which are designed to ensure they are accessible for future reference and are reliable, and that hey maintaim the integrity of the information communicated. The ETA does not efer to digitial signatures specifically because by doing so it could be interpreted as being tied tio a particular electronic signature technology. Instead the Act focuses on the basicc requirements of a signature and this is important considering the sgnificance of both signature and writing in many transactions.

A person must consent to receiving electtronic communications from the Government. Consent can be inferred from a person's conduct. Express consent is not required. The consent provisions however ' do not extend to Commonwealth entities (Giles, 2000).

As the Commonwealth is exluded from the operation of the consent provisions, Agencies must accept electronic communications. However, the Commonwealth is given certain specific powerss. The ability to satisfy a legal requirement electronically is condtional upom a person complying with any particular information technology requirements for communication with a particular Commonwealth agency, including amy particular electronic signature technology that must be used, and any action a person must take to verify receipt of information.

The ETA also sets out default ules that apply in the absence of any contrary agreement between the parties. Thes include regulations that deem the time and place of dispatch and receipt of electronic communications, and the attribution of electronic communications. 
The ETA also provides that any other lawsthat deal specifically with the use of ellectronic communications to satisfy writing, signature, production or retention requirements will be preserved (Australian Arciives, 1999). The ETA does not override any existing laws that deal specifically with these matters.

\section{An Assessment of the ETA}

The ETA has only just begun its journey in acieving its broad objectives. The hurdles along this journey may however le summarised in three words: workability, practicality and techmicality.

\section{Workability}

The workability problems stem from the Conronwealth's decision to leave it to the States and Territories to adoptt the model egslation. The Government rejected the option of a comprehensive Commonwealti legislation because of concerns that such a scheme would be open to constitutional challenge. Two issues emanate from this statement.

First, a key objective of the ETA is to place e-commerce legally on the same footing as paper-based transactions. However, one leading observer in this area and a member of the Governmentt's ECEG his argued strongly that 'this objective simply cannot be achieved without a single pece of Federal legislation that covers the ffield [emphasis added]. Any prospect of each State doing its own thing would be unworkable. It would be as inappropriate as having each State enacting different legislation to cover air, navigatior or space travel' (Canberra Times, 1999:13).

As well, the need to pass nime separate jieces of legislation, is likely to give rise to other problems. These were foreshadowed in the explanatory memorandum to the ETA (AGD, 1999:10) wiich states:

'...the aim is to increase certainty and encourage business and community confidence in electronic tansactions. This aim may be hindered by a number of factors. Uuiform legislation can be time consuming to negotiate and tenact, which means that existing uncertainty will continue during that prosess. In adcition, there is the possibility that some or all of the jurisdictiions may cloose not to be involved in the negotiation of the legislation or not to enact the agreed uniform legislation if it is perceived as not siting their particular interests. Alternatively, jurisdictions may alter he uniform law, either in the course of enactment or subssequently, psssibly by adding on provisions that deal with matters not covered by he uniform law. Any of these results would undermine the; goal of national uniformity...'

Given the past difficulties of trying to ass uniform Australian Fair Trading legislation, Credit Code and Corporations Lav, this issue is a genuine concern and 
a real hurdle. Another problem is that courts in the different jurisdictions may adopt different approaches in their interpretations of the ETA. This is because each state and territory has a diffeent Acts Intcerpretation Act and use different Evidence Codes. These regulations are not unilform in their treatment of digital documents.

The second issue is the Governnent's perceiived lack of constitutional powers to pass legislation in this area. Considered constitutional opinion suggests that the ETA can be made to apply to all trarsactions in Mustralia affected by e-commerce. Such a law is plainly a bona fide lav with respect to trade and commerce. Thus, the failure to propose a universal feleral law maay be an attempt to accommodate the wishes of the different states.

From another viewpoint, the ETA is less likely to result in a constitutional challenge given economic realities and international developments. In strategic terms Australia may now have los the chancee to play a more pro-active and leading role in the development of ecommerce and indirectly to benefit from this in economic terms. E-commerce levelopmentt may have already been stunted given Australia's lack of a legal infastructure im place. The prospect now seems that undue time and effort may neei to be spentt in sorting out compliance issues across the different legal jurisdictons. This: is hardly being pro-active nor undertaking legislative reform. The irony is that the rapid emergence of new technologies, practices and internaional devellopments may compel Australia, whether it wishes to or not, to pass iniform legisslation in order to comply with its international obligations.

The view here is that the Commonwealth has the power to deal with electronic transactions and should propose a law that is both comprehensive and uniform for all of Australia. The eality is that there are no state markets but Australian markets. Furthermore, this marketplace is increasingly becoming a 'global' one that requires laws havirg both the breadth and reach to deal with this new, emergent reality.

\section{Practicality}

There are in addition practical probems in the implementation of the ETA. First, all Government agencies will have to survey and determine what laws apply to them. Second, agencies must decid: whether excisting requirements of a 'writing' and a 'written signature' should be exempted from the legislation. Third, agencies must assess the underlying policy reasons for recquiring writing and/or a signature. In retrospect, there are many policy as well as historical and practical reasons for requiring such 'formalities' (Sneddon, 2000). 'For example, a written signature may be required for evidentiary puposes. It may also be required for cautionary purposes - the requirement of a signature maly make a person realise that the document is an important one and that it has legal consequences. The requirement that parties use a particular form in a designateed order may have a channelling function to structure the transacton in a particular way. Yet, digitisation 
encourages disintermediation — the middle step — and thereby may defeat the channelling function.

Formalities such as signaturres serve the evidentiary function in order that these can be later used to prove an fact and br available as admissible evidence in court. This may prevent fraud, pperjury and other improper conduct because the signature may be used among othier things toidentify the signer by name; provide evidence that the signer has agreed to be bund by the record by adopting or approving it; to prove authenticityy and voluntriness of another signature; to prove originality and prima facie evidkence that the record is a true copy of another record. Of course, there are numerous othe examples why a signature may be important. The need for writing; thus discourages reliance on oral statements or agreements which are not permamently recorled by other media which may more easily be disputed and be more cosstly to provi when a disagreement arises.

The cautionary function encourages the igner to deliberate and reflect before putting signature to paper. This may forewan the signer that the document brings with it legal consequences and whether or not they wish to be legally bound. Especially in consumer protecttion, this sautionary function is particularly important. The cautionary function may also be interpreted as a protective one because people receiving or relyiing on a doument may now have evidence that the maker of the document has given their full attention to the document and according to the context has authored, adopted or verified the contents of the document.

The channelling function clarrifies the disinction between the intent to act in a legally significant way and the imtent to act therwise. This is particularly so in the public arena where there are: forms to b: used mainly because of legislative requirements and information cof a particlar kind may be required. The government agency may have sspecific requirements say, in the social security area, tax, licences and so on. To : a lesser extent the person lodging such forms, by writing in the answers on a physsical medium provides the reassurance that the content is recorded in a durable: fashion raher than captured only in memory, human or otherwise. This alome, might cution people to take care in what information they provide and on what media.

Finally, the writing and signnature requirements may relate to storage and record keeping functions. Such füunctions anc their underlying policy reasons may vary greatly depending upon whether we are talking about police records, tax files or whatever. All of these imply that agendes face the problem of developing, configuring and re-engineering their information systems and administrative standards to implement, receive, process, issue and store records in an electronic format. As a result there is the neeed to estabish standards, processes and controls on the use, authentication, storagge and retrieval of documents in electronic form. Needless to say, these tasks are neeither easy nor are they 'cost neutral'. 


\section{Technicality}

A third area of difficulty is the lenguage of the ETA. Of necessity the language used in the Act is quite broad in crder to cover a wide range of applications. Concepts such as 'notice', 'corsent', and 'as reliable as appropriate for the purposes for which it was comnunicated' are: likely to give rise to differing interpretations by the various Stae and Territoryy Courts. In reality, it may be of comfort to think that one may raly on 700 years or so of legal precedents for interpreting such words as 'writing', "signature', 'verification" and 'acknowledgment'. However, one can be less ssanguine where judicial decisions hinge on interpreting digital siguatures given the rather vague language of the ETA.

In implementing the public key infrastructure and authentication framework (PKAF) for the information econom?, the Government has put in place principles and standards by which electronic signatures may be used in electronic communications with public agencies. The concern here is the extent to which an individual may be able to have more than one dicgital persona - individually as a person and corporately as a company or business entity. Also, there is the issue of whether the digital signature is to ie used either for security or authentication purposes or for both functions.

Digital signatures are perceived to be foolproof given the security technology in place. However, the very basis of a signature's integrity will depend on how secure is the process by which the $\varepsilon$-signature was created. While it is true that even with hand-written signatures forgeries may/ be perpetrated, the public needs to be reassured of the security of erignatures. IBiometric systems such as finger print authentication, iris scans and the like are equally vulnerable to 'attack'. One should also be constantly reminded hat an authentication of an e-signature is very different from its security. Indeed the very use of e-signatures in electronic communications with a public agency suggests a loss of anonymity. Compared to most other transactions between individuals sucth as in the marketplace, in cashbased transactions, or even in conversations with the person sharing the seat on a bus, it is possible to remain anonymus.

Also, there may appear to be undue optimissm over how quickly e-signature infrastructure can be developed to provide a workable and reliable system on which businesses can rely. Much mire thought and evaluation may be required on the meaning, use and implications ofthe concept of persona and identities whether it be personal or business. Moreover, there may be other forms of electronic authentication and manuscript metlods that may be used that may offer more advantages than those proposed under the PKAAF regime. Many technological issues seem to have been glossed over but which may have important legal implications when these reach the cartrooms of the future. 


\section{Some Broad Observations}

In parsing the ETA, the federal grovernment lastaken a lead role in facilitating ebusimess first with all governmemt agencies anc later for all forms of electronic transiactions. In creating a 'light-handed rigulatory regime for the use of ecommerce in transactions' the gowernment hopes to encourage the development of the mew (information) economy and informition communication technology in Australia (NOIE, 1999b). Anyome can now chcose to use electronic transactions when dealimg with government agencies. The legislation has removed a number of legal impediments in such ttransactions where there is now a functional equiwalence between paper-based and electronic transactions and is technology neutral. The ETA has clarified the legal status of electronic transactions. In this respect the government is highlly supportive of innovation and its legislative framework is consistent both locally and intenationally.

Yet, the devil is in the detail. Close exanination of the Act suggests several areas of concern including its workability, practicality and technical imperatives. A uniform federal legislation is more desiratle than separate pieces of state and territory legislation on the same subject mater. This will avoid differences in judicial interpretation and evidenitiary requirments. There do not appear to be constitutional impediments that will prevent such a move. It may be wholly impractical to implement the Arct in stages and more importantly deal with 'detaills' such as writing and writteen signature that different government agencies may require. Jurisprudence sugggest the diferent functions that these detailed requirements serve - as evidence, as a precaution, as a particular channel or process. Finally, the broad language of the EГA cuts both ways in that it may be flexibly interpreted and at the samie time may nake it more difficult to prosecute.

That the government has achieved its gcals with the passage of the ETA is undoubted given that its intentiosns were sinply to put in place legislation to facilitate e-commerce in the first place. Howzver, it may be sometime yet before one can truly assess whether the ETA has worked to bring about uniformity of laws and regulations and the promtotion of e-commerce. At the very least the ETA may encourage and has put in placce the legal infrastructure for anyone to transact business with any government agrency electronically. Moreover, the legislation may be seen to promote greater competitiveness in the brave new world of ecommerce and e-government.

As it stands, the ETA may need to undergo several iterations and amendments before it will fully acchieve all the objectives the government has set itself in the area of e-commerce. However, in the further evolution of the ETA what should be avoided is the formulation oi rules and regulations that become both fixed and inflexible in time. Past xperience shows that information communication technology may owertake suchformulations very quickly.

On a world-view Australial will have to keep pace with international developments. As technology transcends naional boundaries and globalisation continues apace, Australia's expeeriences can contribute to the development of uniform international e-business latw. In doingso, however, there is a greater need 
to ensure that personal privacy is protected by preventing the misuse of technology.

Australia has adopted a light-handed approach to the regulation of ecommerce. Likewise, the US his advocated minimal regulation of on-line commerce. By contrast, the Eurcpean Union has proposed a more intrusive approach that includes regulation of cross-border data transfers through to ensuring that labour, environmenta and tax standards are incorporated in all ecommerce laws.

Australia has led by exampl in attempting to regulate and facilitate ebusiness with government agencies. This alone may engender greater confidence in transacting business electronicaly. Whether this will generate more businessto-business transactions in the privite sector and in turn become more profitable for the economy as a whole only time will tell. Nevertheless, the passage of the ETA is a step in bringing order in apreviously unregulated digital frontier.

\section{References}

Australian Archives (1999), 'Electronic Commerce'

(http://www.naa.gov.au/recordkeeping/sr/ecec_comm.html).

Australian Financial Review (1999), 'Internet and E-commerce: Special Report 1999: In Search of Planet Profit', 9 March:50.

Australian National Audit Office (199-2000), Electronic Service Delivery, Including Internet Use, by Commonwealth Agences, Audit Report No 18, (http://www.anao.gov.au).

Australian Taxation Office (1997), Ebctronic Commerce Report: Tax and the Internet (http://www ato.gov.au/ecp/ecp.htm).

Attorney-General's Department (199), 'Draft Electronic Transactions Bill 1999: Explanatory Paper', (http://www.searh.aph.gov.au/search/ParlInfo...9).

Canberra Times (1999), 'Legal Expert's Jurisdictional E-commerce Misgivings', 1 February: 13.

De Zwart, M. (2000), 'Electronic Commerce: Promises, Potential and Proposals', UNSW Law Journal, May, (http:/www.law.ursw.edu.au/unswlj/ecommerce/zwart.html).

Electronic Commerce Experts Group (1998), Electronic Commerce: Building the Legal Framework, (http:/www.law.gov.au/arhome/eceg/ecegreport.html).

Federal Bureau of Consumer Affairs 1997), Untangling the Web: Electronic Commerce and the Consumer, Austalian Govemment Publishing Service, (http://www.dist.gov.au/consumer.htmi)

Giles, D. (2000), 'You've Got Mail ... or Have You?', Internet Law Bulletin 3(1):12-14. 
National Advisory Council on Consumer Affars (1998), Consumer Protection in Electronic Commerce: Principles and Key Issues Department of Industry, Science and Resources, Canberra (http://www.dist.gov.au/constmer/eleccomm/princip.html).

National Office for the Information Economy (199a), A Strategic Framework for the Information Economy: Identifying Priorities for Ation, Department of Communications, Information Technology and the Arts, Canberra (http://www.noie.gov.au/nationalstrategy/index.htnl).

National Office for the Information Economy (1999b), E-commerce Beyond 2000, Departmentt of Communications, Information rechnology and the Arts, Canberra (http://www.noie.gov.au/ecom/HOME/Policy/Econmic_Impacts_Study/economic_impac ts.html)

Sneddon, M. (2000), 'Legislating to Facilitate Electronic Signatures and Records: Exceptions, Standards and the Impact of the Statte Book', UNSW Law Journal, May, (http://www.law.unsw.edu.au/unswlj/ecommerce/sieddon.html).

UNCITRAL (1996), 'Model Law on Electronic Commerce with Guide to Enactment, General Assembly Resolution 51/162', Draft Unform Rules on Electronic Signatures, Working Group on Economic Commerce (http/www.uncitral.org/english/sessions/wgec/wp-82.pdf) and UNCITRAL, 'Uniform Rules on Electronic Signatures - Australian Issues Paper' (http://law.gov.au/publications/ecomnerce/welcome.html).

The authors would like to thank the two anonymous referees of this article for their consitructive and useful criticisms, which considerably improved the final version of this paper. Thanks also go to our sudents and University of Canberra colleagues for their ideas and encouragemint to keep working in this most exciting area of the law. 